\title{
2.5 Архітектурна система та архітектурна структура
}

Архітектура є невичерпним джерелом інформації про життя суспільства, науково-технічний потенціал, ідеологію та мистецтво. Саме тому ії називають літописом світу. Архітектура є одною з тих дисциплін, що потребує постійного вивчення, дослідження та вдосконалення. Така діяльність дає змогу ознайомитись зі своєрідністюю конструктивних рішень.

Архітектурна фундаментальна наука відноситься як до технічних наук, так і до суспільних наук. Основне завдання архітектури - це створення штучного довкілля, що можна вважати комплексною задачею. Архітектура може поєднувати в собі багато аспектів, зважаючи на те, що сучасне будівництво базується як на суспільних, технічних науках , так і на нанотехнологіях. Але, архітектура має своє місце у ряді академічних наук, а саме тому вона має свою систему та структуру.

Існує варіант розгляду архітектури і їі окремих процесів як мовного явища. Тут варто згадати американського архітектора та творця органічної архітектури

- Ф.Л. Райта. Він був одним 3 перших, хто використав термін «граматика архітектурних форм» у своїх наукових роботах. Однак, архітектор вважав, що коли мова йде про способи поєднання простору, то треба використовувати термін « синтаксис архітектурних форм».

Результати архітектурної творчості можуть бути представлені як носії матеріальної та духовної цінності, а саму архітектуру потрібно розглядати як окреме явище, в якому можна виділити три актуальні області.

Насамперед слід згадати професійне навчання архітекторів в архітектурних школах, коли навчання проектуванню здійснюється так само за чіткими «граматичними» законами.

Другий аспект пов'язаний із тим, що архітектура як культурне явище може досліджуватися з естетичної точки зору. 
Останній, третій напрямок - це розгляд архітектури як системного структурного явища, що вимагає іiї вивчення як культурної та технологічної системи, що володіє геометричними, топологічними та цілісно-системними властивостями.

Розглядаючи архітектуру як системне явище треба виділити два напрями. Перший охоплює вивчення архітектурних форм та параметрів опису їхньої будови. Другий напрямок має справу з семантикою, тобто, системою значень, що надаються архітектурною формою, тому, як вони структуруються, як існують i як розвиваються.

Слід зазначити роботи, присвячені цьому напряму, таких вчених, як Норберг-Шульц, Ж.Х. Бонта, Ж. Бродбент, Л. Марч, Г. Віллоубі, В. Мітчелл. Їх дослідження планувальної будови архітектурних об'єктів спиралися на певні розділи математики, геометрії, графоаналітично теорію і теорію симетрії.

В основі цих досліджень лежить припущення, що вивчення геометричних обмежень просторового розгортання архітектурних об'єктів (у тому числі і містобудівних) допоможе архітектору-проектувальнику при вирішенні завдань професійної підготовки, так і при вирішенні практичних завдань проектування архітектурних об'єктів.

Ti, хто займались такими дослідженнями, математичні знання розглядають як вагоме доповнення до розумового процесу, що пов’язаний з архітектурною діяльністю. Що більше, стає очевидно, що комп’ютерна техніка неминуче все більше буде займати місця у діяльності архітектора, а математичні навички $є$ важливими для роботи з сучасними комп’ютерними програмами.

Математична компетентність підвищує професійну цінність проектувальника та дає більше можливостей для розвитку та діяльності.

Можливо тут варто роздумувати над розробкою програм, що будуть генерувати ймовірно «оптимальні» архітектурні рішення 3 урахуванням критеріїв різного роду.

Критерії обліку геометричних, топологічних, комунікаційних, технічних та інших обмежень під час виконання компонування плану необхідні під час 
розгляду варіантів планувальних рішень 3 використанням об'єктивно сформульованих методів їх генерації.

Можна сказати, що сама архітектура є багаторівневою системою, якій підвладні безліч взаємозалежних елементів і підсистем, що утворюють ієрархію в рамках цілого і включають до свого складу окремі елементи одного виду. В такому випадку більше уваги треба приділяти не стільки основі архітектурних елементів, скільки їх реляційним характеристикам, які набуваються ними в результаті функціонування у структурі архітектури.

Можна сказати, що архітектура зводиться певним способом до структури, точніше до мережі відносин між її елементами. В такому разі, можна оголосити про залежність кожного архітектурного елемента від структури, до якої він належить, та від його місця відносно інших елементів.

Розгляд просторової організації архітектурних елементів дозволяє проаналізувати та виділити узагальнені інваріативні одиниці - просторовопланувальні рішення і спів віднести їх з конкретними просторовими ситуаціями з урахуванням строгих правил їх просторової реалізації.

Прикладом такого аналізу можна вважати роботу Роба Кріє «Architectural composition» (1988), у якій робиться докладний розбір будови архітектурних об'єктів в історичній ретроспективі з позицій їхньої особистої творчої оцінки. Р. Кріє розбирає обумовленості архітектурної форми з чотирьох позицій:

• по-перше, взаємозалежність форми та функції ;

• по-друге, розглядається форма як архітектонічна система організованих елементів;

• по-третє, окремі елементи , що визначають архітектурну форму;

• по-четверте, архітектурна форма як результат співвідношення пропорцій.

Така система дає змогу охопити головні описові характеристики для будьякої архітектурної форми, включаючи як природньо-фізичний аспект, так i художньо-виразний.

Гармонічний взаємозв’язок функції та форми в архітектурному об’єкті приводить нас до розуміння системності та цілісності архітектури. Саме функція 
задає типологічно стійкі образи в архітектурі. Це своєю чергою призводить до впізнаванності будівлі.

Друга позиція опису - архітектоніка форми - визначає опис системних властивостей, що виявляються в будові архітектурних об'єктів і описуються складними матрицями, побудованими з різних підстав: точка - лінія - площина обсяг - внутрішній простір - зовнішній простір; графіка - пластика - архітектура - урбанізм; регулярна геометрична форма - нерегулярна хаотична форма копіювання та доповнення - гетерогенні форми.

Подібні матриці дозволили Р.Кріє описати 3 єдиних позицій все образотворче «поле» художньої творчості художника, яким може бути i скульптор, i дизайнер, i фотограф, і графік, i архітектор. Всі вони у своїй творчості займаються пошуком виразності форми, її тектонікою, мотивацією для якої може стати будь-яка із заданих їм підстав.

При розгляді архітектури з точки зору класифікації наук, треба виділити три окремі розділи для досліджень, що включають інновації на стику 3 технічними науками, на стику із суспільними науками та 3 природознавством. Зважаючи на все це, можна сказати, що архітектура охоплює широкий спектр дисциплін, які мають гармонійно поєднуватись та взаємодіяти під гаслом архітектурної творчості.

Усі етапи розвитку архітектури характеризувались великою кількістю суперечок щодо ऑii місця серед інших наук. Архітектура пройшла тривале становлення від періоду моністичних знань до власної диференціації, коли науковці підрозділяли їі на декілька окремих предметів, що формували окремі дисципліни. Наразі технічний прогрес вимагає чіткої систематизації знань а сама архітектура потребує гострого синтезу здобутих знань .

Науково-технічна революція поставила перед людством багато нових завдань. Прискорення розвитку нових технологій потребує швидкого навчання та впровадження. Якщо раніше зміни навколишньої дійсності були одиничними та припадали на декілька століть. То тепер їх можна спостерігати неодноразово протягом життя одного покоління. Містобудування є багатоскладною та 
трудомісткою сферою, однак разом і 3 тим найінертнішою, бо у 21 столітті нововведення будуть впроваджуватись кожні 50 років, що у 10 разів більше, ніж у інших сферах діяльності людини. Це пов'язано з дедалі більшою концентрацією населення у містах, необхідністю покращувати та розвивати інфраструктуру транспорту, туризму, виробництва, зводити житло, загалом забезпечувати зростаюче населення планети об'єктами, що формують матеріальне середовище життедіяльності.

При цьому вимоги до якості штучного довкілля людей постійно підвищуються. Нові технології дозволяють реалізувати абсолютно фантастичні проекти у змісті яких приховані зусилля великого загону спеціалістів. Вони забезпечують «міцність та користь» у контексті глобальних викликів сучасності, використовуючи нові методи розрахунку та конструювання проектованих об'єктів. У їх зовнішній формі та внутрішньому просторі реалізуються вимоги «краси», закладаються глибокі філософські та естетичні концептуальні ідеї, привабливі для професіоналів та масових споживачів мистецтва архітектури.

Сучасна архітектурна освіта має відповідати викликам нового часу. Середовище повсякчас змінюється, а професійні завдання стають все складнішими. Студенти мають отримувати актуальні знання, що не застаріють на етапі отримання диплому.

Введення в ужиток сучасного архітектора комп'ютерної техніки дозволяє підвищити якість технічної проробки проектів, прискорити процеси обгрунтованості, можливості нелінійного програмування, відкривають шляхи прийняття проміжних рішень по ходу виконання проекту на різних стадіях і при цьому включати можливості техніки в творчий процес архітектора, повніше та багатостороннє враховувати природні геометричні та структурно-топологічні обмеження формоутворення.

Вирішення проблем впровадження комп'ютерного проектування визначить низку нових напрямів архітектурної діяльності, пов'язаних з умовами проектування, використанням необхідної техніки та програмного забезпечення у практиці проектування, комп'ютеризацією процесів професійного навчання та 
неминучим коригуванням самих навчальних програм, орієнтованих на нові методи проектування та будівництва.

Впровадження в програми навчання нових методик, заснованих на структурному трактуванні будівлі архітектурних об'єктів, ознайомлення 3 логікою природного формоутворення у реальному просторі ув'язування архітектури з усім предметно-просторовим штучним та природним оточенням, 3 одного боку, продовжить традиції Л. Да Вінчі, А. Дюрера та Кр. Рейя, які бачили в архітектурі не протиставлення природі, а наближення до неї та вписування у логіку їі розвитку.

Архітектори та студенти вже сьогодні використовують комп'ютерні моделі - віртуальні, кібер-реальні, і в найближчому майбутньому слід очікувати на розширення сфери їх застосування для вирішення професійних завдань. Комп'ютерні моделі стають найбільш перспективними в архітектурному проектуванні та навчанні.

Таким чином, архітектурна система визначається як умоглядно пов'язана сукупність фактів штучного середовища оточення людини та лежачих у їі основі механізмів їх природного існування.

Архітектурна система передбачає багаторівневу організацію 3 наявністю підсистем, що співвідносяться 3 вже сформованою в архітектурі об'єктної масштабно-цілісної класифікації: інтер'єрна організація об'єкта, що передбачає цілісну побудову його внутрішнього простору; об'єкт (будівля, споруда) як самостійна одиниця, протиставлена зовнішньому оточенню; комплекс об'єктів 3 включенням їх внутрішніх та зовнішніх просторів (багатофункціональні комплекси, житлові освіти, квартали, населені пункти, фрагменти міського середовища); містобудівні комплекси, де простір замінюється поняттям території, але ще не зменшує своєї пропорційності людині.

Виділення підсистем в архітектурній системі необхідно у зв'язку 3 необхідністю визначення об'єкта архітектури як цілісної структурної одиниці відповідного ітераційного рівня. 
3 архітектурною системою також співвідноситься поняття архітектурної структури як абстрактної мережі співвідношень різних частин архітектурного об'єкта, тобто їхню просторову структурну організацію.

Структура являє собою сукупність стійких зв'язків об'єкта, що забезпечують його цілісність та тотожність самому собі, тобто збереження основних властивостей при різних зовнішніх і внутрішніх змін.

У вище приведеному зіставленні слідує Важливо відрізняти поняття архітектурної системи та структури.

Система - це реальний феномен, явище, об'єкт чи їхня група, розглядаються як сукупність пов'язаних певним чином складових частин, тоді як структура $\epsilon$ абстрактною мережую відносин цих елементів. Тому кожна архітектурна система завжди передбачає наявність у ній своєї структури.

Структура не може бути створена штучно, безвідносно до будь-якої архітектурної системи.

За зовні простим процесом організації архітектурного простору, що зводиться до членування цілого на частини, з'єднані по певним закономірностям, ховаються фундаментальні властивості архітектурного простору.

3 цих закономірностей випливають численні формально-логічні та практичні наслідки, що базуються на тому, що структурні властивості простору архітектурних об'єктів лежать в основі прояву загальних закономірностей реалізації процесів формоутворення, серед яких головними є геометричні, топологічні та цілісні. 